\title{
Pricing mechanism of carbon emission rights and its effectiveness research -- based on case analysis of carbon emission trading centers in Beijing and Guangzhou
}

\author{
Fazhao Liu \\ Nanjing University of Science and Technology,Nanjing,China \\ 634354345@qq.com
}

Keywords: Carbon emissions, the framework of OLS, effectiveness.

\begin{abstract}
Greenhouse gas emission reduction is a global issue, and the United States' historic carbon dioxide emissions require it to bear the corresponding financial responsibility in the Paris agreement. Mr Trump therefore decided to withdraw from the Paris agreement. Neither can the US withdraw from the Paris agreement reverse the US-led North American carbon pricing system, nor the EU and other countries' carbon pricing and emission reduction systems. The government of the carbon pricing mechanism and China's carbon market pricing system of national unity has begun to take shape the global carbon market pricing mechanism, and the in the future carbon resource allocation, carbon, carbon and political game will play a decisive role in the economic transformation.
\end{abstract}

\section{Introduction}

Greenhouse gas emission reduction is a global issue, and the agreements reached in recent years have laid the foundation for the development of the carbon emission trading model (see table 1). China is the world's largest emitter of greenhouse gases, and emission reduction is inevitable and necessary. On the other hand, emission reduction can achieve energy transformation and energy conservation and emission reduction at the lowest social cost, and also ensure that China will gain an international voice in the new economic rules of the low-carbon economy in the future. Therefore, at the Copenhagen conference, China promised to reduce carbon dioxide emissions per unit of GDP by $40-45 \%$ by 2020 , and defined the relevant top-level design in the 13th five-year plan outline.

Table 1 Major agreements and achievements in global climate cooperation.

\begin{tabular}{|c|c|c|}
\hline Time & $\begin{array}{l}\text { The name of the } \\
\text { protocol }\end{array}$ & The main achievements \\
\hline In 1992 & $\begin{array}{l}\text { United Nations } \\
\text { convention on } \\
\text { climate change }\end{array}$ & $\begin{array}{l}\text { The world's first international treaty to fully control greenhouse gas emissions, } \\
\text { such as carbon dioxide, in response to the adverse effects of global warming on } \\
\text { the human economy and society. This laid the foundation for the regular } \\
\text { convening of the conference of the parties. }\end{array}$ \\
\hline In 1997 & Kyoto protocol & $\begin{array}{l}\text { The United Nations framework convention on climate change third parties to the } \\
\text { convention was held in Kyoto, Japan, and through the designed to limit } \\
\text { greenhouse gas emissions in the developed countries to curb global warming, the } \\
\text { Kyoto protocol. The Kyoto protocol proposes three flexible mechanisms: the } \\
\text { clean development mechanism (CDM), the joint implementation mechanism (JI), } \\
\text { the emission trade (ET) and the carbon emission elimination mechanism } \\
\text { (RMUs). }\end{array}$ \\
\hline In 2007 & Paris road map & $\begin{array}{l}\text { The Paris roadmap defines specific areas and routes for countries around the } \\
\text { world to strengthen the implementation of the United Nations framework } \\
\text { convention on climate change in the future }\end{array}$ \\
\hline In 2010 & The Cancun meeting & $\begin{array}{c}\text { An agreement to provide aid to developing countries to reduce their carbon } \\
\text { emissions }\end{array}$ \\
\hline In 2011 & Durban climate & Decision to implement phase ii commitment to the Kyoto protocol (2012-2020 \\
\hline
\end{tabular}


conference

\section{Empirical study on the effectiveness of carbon market pricing in Beijing and Guangzhou}

\subsection{Data and variables}

The research range of this paper is July 1, 2014-June 30, 2016. The choice of the time, on the one hand, considering our country's carbon emissions trading market (hereinafter referred to as the "carbon trading market") to start soon, in July 2014, before trading can be affected by interference and the policy is more, can't measure market pricing efficiency; On the other hand, the selected time period basically covers the complete year of performance, which is more meaningful.

\subsection{The empirical analysis --the framework of OLS}

In this paper, the validity of the carbon market pricing mechanism in Beijing and Guangzhou is first tested under the OLS framework. The measurement equation is as follows:

$$
\text { CAP }_{t}=\beta_{0}+\beta_{1} \times \text { CAP lag }_{\text {lag }}+\beta_{2} \times \text { Coal price }_{t}+\beta_{3} \times \text { Elec }_{t}+\varphi \times X_{t}+\varepsilon_{t}
$$

In the above equation, CAP and Elec are respectively the abbreviations of carbon emission right price and power price index. Under this framework, this paper focuses on the relationship between the price of carbon emission rights, its lagging term and the price of bituminous coal.

The table 2 reflects the pricing of carbon trading in Beijing. The positive and significant influence of the price of carbon emission rights in the lagging phase of carbon emission rights proves that carbon emission rights already have the property of financial assets.

Table 2 Carbon pricing in Beijing market.

\begin{tabular}{|c|c|c|c|c|c|c|}
\hline Variables & Model(1) & Model(2) & Model(3) & Model(4) & Model(5) & Model(6) \\
\hline Carbon allowance price t-1 & $\begin{array}{c}0.631^{* * *} \\
(0.158)\end{array}$ & $\begin{array}{c}0.494 * * * \\
(0.173)\end{array}$ & $\begin{array}{c}0.396^{* *} \\
(0.155)\end{array}$ & $\begin{array}{c}0.389 * * \\
(0.156)\end{array}$ & $\begin{array}{c}0.295^{*} \\
(0.168)\end{array}$ & $\begin{array}{l}0.301^{*} \\
(0.171)\end{array}$ \\
\hline Carbon allowance price t-2 & $\begin{array}{c}0.120 \\
(0.113)\end{array}$ & $\begin{array}{c}-0.045 \\
(0.116)\end{array}$ & $\begin{array}{l}-0.106 \\
(0.132)\end{array}$ & $\begin{array}{l}-0.104 \\
(0.133)\end{array}$ & $\begin{array}{l}-0.182 \\
(0.133)\end{array}$ & $\begin{array}{l}-0.182 \\
(0.132)\end{array}$ \\
\hline Coal price & & $\begin{array}{l}0.112 * * \\
(0.049)\end{array}$ & $\begin{array}{c}0.294 * * * \\
(0.108)\end{array}$ & $\begin{array}{c}0.307 * * * \\
(0.109)\end{array}$ & $\begin{array}{l}0.167^{*} \\
(0.094)\end{array}$ & $\begin{array}{l}0.183^{*} \\
(0.107)\end{array}$ \\
\hline Gas price & & & $\begin{array}{l}-0.006 \\
(0.004)\end{array}$ & $\begin{array}{c}-0.007^{*} \\
(0.003)\end{array}$ & $\begin{array}{l}-0.007 \\
(0.005)\end{array}$ & $\begin{array}{l}-0.007 \\
(0.005)\end{array}$ \\
\hline Temperature & & & $\begin{array}{c}0.122 \\
(0.104)\end{array}$ & $\begin{array}{c}0.136 \\
(0.107)\end{array}$ & $\begin{array}{c}0.051 \\
(0.083)\end{array}$ & $\begin{array}{c}0.043 \\
(0.082)\end{array}$ \\
\hline Electricity price index & & & & $\begin{array}{c}0.005^{* *} \\
(0.002)\end{array}$ & $\begin{array}{c}0.006^{* *} \\
(0.002)\end{array}$ & $\begin{array}{c}0.006 * * \\
(0.003)\end{array}$ \\
\hline Oil price & & & & & $\begin{array}{c}-0.071 \\
(0.085)\end{array}$ & $\begin{array}{l}-0.053 \\
(0.096)\end{array}$ \\
\hline Paper price & & & & & $\begin{array}{c}-0.038 \\
(0.048)\end{array}$ & $\begin{array}{l}-0.035 \\
(0.050)\end{array}$ \\
\hline Iron price & & & & & $\begin{array}{c}0.205^{* * *} \\
(0.048)\end{array}$ & $\begin{array}{l}0.178^{*} \\
(0.091)\end{array}$ \\
\hline PPI change & & & & & & $\begin{array}{c}-1.179 \\
(1.855)\end{array}$ \\
\hline Policy & & & & & & $\begin{array}{c}0.090 \\
(0.533)\end{array}$ \\
\hline Constant & $\begin{array}{c}11.865^{* *} \\
(4.557)\end{array}$ & $\begin{array}{c}-30.130 \\
(20.938)\end{array}$ & $\begin{array}{c}-91.370 * * \\
(38.302)\end{array}$ & $\begin{array}{c}-95.743^{* *} \\
(38.899)\end{array}$ & $\begin{array}{c}39.983 \\
(111.366)\end{array}$ & $\begin{array}{c}28.704 \\
(112.019)\end{array}$ \\
\hline $\mathrm{n}$ & 47 & 47 & 47 & 47 & 47 & 47 \\
\hline
\end{tabular}

Note: in brackets, the standard error adjusted by Newey-west method is taken, and the lag term is taken. *,** and

*** respectively represent significant at $10 \%, 5 \%$ and $1 \%$ levels.

Compared with the regression results of Beijing carbon market, the empirical analysis of Guangdong carbon market presents interesting conclusions. The carbon emission right in Guangdong market has a stronger financial asset nature. According to the results in the table below, 
the price of carbon emission rights is highly correlated, which may be because of the large scale of the carbon market in Guangdong, whose average daily transaction volume is about 4 times that of the Beijing market. Therefore, speculation and arbitrage are more common in the market.

Table 3 Pricing of carbon emission rights in Guangzhou market.

\begin{tabular}{|c|c|c|c|c|c|c|}
\hline Variables & Model(1) & Model(2) & Model(3) & Model(4) & Model(5) & Model(6) \\
\hline Carbon allowance price t- 1 & $\begin{array}{c}0.474^{* * *} \\
(0.092)\end{array}$ & $\begin{array}{c}0.461^{* * *} \\
(0.095)\end{array}$ & $\begin{array}{c}0.463 * * * \\
(0.097)\end{array}$ & $\begin{array}{c}0.414^{* * *} \\
(0.101)\end{array}$ & $\begin{array}{c}0.365^{* * *} \\
(0.118)\end{array}$ & $\begin{array}{c}0.372 * * * \\
(0.113)\end{array}$ \\
\hline Carbon allowance price t-2 & $\begin{array}{c}0.338 * * * \\
(0.112)\end{array}$ & $\begin{array}{l}0.317 * * \\
(0.121)\end{array}$ & $\begin{array}{c}0.320 * * \\
(0.118)\end{array}$ & $\begin{array}{c}0.369 * * * \\
(0.115)\end{array}$ & $\begin{array}{c}0.284 * * \\
(0.111)\end{array}$ & $\begin{array}{c}0.258 * * \\
(0.118)\end{array}$ \\
\hline Coal price & & $\begin{array}{l}0.025 * * \\
(0.026)\end{array}$ & $\begin{array}{c}0.002 \\
(0.061)\end{array}$ & $\begin{array}{c}0.002 \\
(0.052)\end{array}$ & $\begin{array}{c}-0.018 \\
(0.132)\end{array}$ & $\begin{array}{c}-0.023 \\
(0.139)\end{array}$ \\
\hline Gas price & & & $\begin{array}{c}0.001 \\
(0.002)\end{array}$ & $\begin{array}{c}0.001 \\
(0.002)\end{array}$ & $\begin{array}{c}-0.002 \\
(0.003)\end{array}$ & $\begin{array}{c}-0.002 \\
(0.002)\end{array}$ \\
\hline Temperature & & & $\begin{array}{c}-0.007 \\
(0.083)\end{array}$ & $\begin{array}{c}0.074 \\
(0.111)\end{array}$ & $\begin{array}{c}0.070 \\
(0.159)\end{array}$ & $\begin{array}{c}0.010 \\
(0.174)\end{array}$ \\
\hline Electricity price index & & & & $\begin{array}{c}0.012 * * * \\
(0.002)\end{array}$ & $\begin{array}{c}0.010^{* * *} \\
(0.003)\end{array}$ & $\begin{array}{c}0.011^{* * *} \\
(0.003)\end{array}$ \\
\hline Oil price & & & & & $\begin{array}{c}0.086 \\
(0.071)\end{array}$ & $\begin{array}{c}0.066 \\
(0.074)\end{array}$ \\
\hline Paper price & & & & & $\begin{array}{c}0.003 \\
(0.021)\end{array}$ & $\begin{array}{c}0.005 \\
(0.024)\end{array}$ \\
\hline Iron price & & & & & $\begin{array}{c}0.049 \\
(0.117)\end{array}$ & $\begin{array}{c}0.080 \\
(0.129)\end{array}$ \\
\hline PPI change & & & & & & $\begin{array}{l}2.104^{*} \\
(1.182)\end{array}$ \\
\hline Policy & & & & & & $\begin{array}{c}0.642 \\
(0.497)\end{array}$ \\
\hline Constant & $\begin{array}{c}3.192 * * * \\
(1.002)\end{array}$ & $\begin{array}{c}-8.729 \\
(11.974)\end{array}$ & $\begin{array}{c}-0.677 * * \\
(20.921)\end{array}$ & $\begin{array}{c}-7.559 * * \\
(17.616)\end{array}$ & $\begin{array}{c}39.983 \\
(111.366)\end{array}$ & $\begin{array}{l}-10.427 \\
(60.859)\end{array}$ \\
\hline$n$ & 47 & 47 & 47 & 47 & 47 & 47 \\
\hline
\end{tabular}

Note: in brackets, the standard error adjusted by Newey-west method is taken, and the lag term is taken. ${ }^{*}, * *$ and *** respectively represent significant at $10 \%, 5 \%$ and $1 \%$ levels.

\section{Conclusions}

From the perspective of the overall operation of the carbon market, the carbon emission trading market in Guangzhou is more effective. Two different main driving factors of pilot carbon trade market price can be summed up in: two places have different market characteristics of the carbon market; and business and trading activities are different. In comparison, the size of the carbon market in Guangdong is larger, the average daily trading volume of about 4 times the left and right sides of the market, however, Beijing market is more active. Specifically, Guangzhou carbon market reflects the price of carbon emission rights under the influence of coal price and the spot price of iron is not remarkable phenomenon may be the main energy prices in the market and the substitution effect of offset by steadily rising energy usage, and the offsetting effect is not obvious in the carbon market in Beijing. At the same time, due to two different pilot market coverage in enterprises, Guangzhou carbon market coverage is relatively wider, and it also led to the PPI rose to bring production recovery effect apparently. So the PPI for Guangzhou price of carbon emissions is more significant and the influence of the carbon price in Beijing drivers do not show up in the impact.

\section{References}

[1] Haowu Chen. Carbon trading topic (2) carbon wind: a national carbon trading market is in the ascendant, with the highest added value of technology and finance. Guangda securities research institute.(2015)

[2] Shuang Zheng. Research report on pilot carbon trading in seven provinces. Energy and 
environment.(2014)

[3] Na Liu. Feasibility study and framework design of China's carbon trading market Beijing: Beijing forestry university.(2010)

[4] Ting Li. Reformed the economic development mode and vigorously developed the low-carbon economic price theory and practice. (2011), 7 (6): 16-17

[5] Yu Fu. The establishment of China's carbon trading market. Nanjing Forestry University. (2007)

[6] You Chen. Carbon finance: opportunities and challenges for China's commercial Banks. Financial science. (2014), 33 (11): 8-15 